\title{
Government Inspectors' Penalties and Customer Loyalty of Investment: Empirical Research based on Data of Chinese Public Companies
}

\author{
Ye Lu \\ Yubo $\mathrm{Li}$ \\ Accounting Department, SHU-UTS SILC Business School, \\ Shanghai University, China
}

\section{Doi:10.19044/esj.2018.v14n16p21 URL:http://dx.doi.org/10.19044/esj.2018.v14n16p21}

\begin{abstract}
This paper uses data of Chinese public companies from 2004-2015 to test the relationship between government inspectors' penalties and customer loyalty of investment bank. The test results show that penalties from government inspectors would damage the reputation of investment bank and, thus, result to a decline in its market competitiveness. If the investment bank gets penalties, IPO customers would probably change the underwriters if they want to do Seasoned Equity Offering (SEO). This, therefore, result to a decline in the customer loyalty of investment bank. This negative impact of penalties on customer loyalty is more significant to the investment bank that has high reputation.
\end{abstract}

Keywords: Government inspectors' penalties, customer loyalty of investment banks, reputation

\section{Introduction}

Investment bank is one of the most important financial intermediaries in the capital market. The quality of equity that was underwritten by investment bank has a significant impact on the development of financial market. Some researches show that the equity underwritten by investment banks with high reputation normally has low earnings management level and low IPOunderpricing on the first day, but the long-term return of this equity is high (Carter, Dark \& Singh, 1998; Jo et al., 2007; Chang et al., 2010). Hiring investment bank with high reputation could help companies to send a positive signal to the open market, reduce the information asymmetry between issuers and investors, and increase issuing price and lower the cost of financing. Investment bank could also expand market share and generate high 
underwriting fee. Normally, investment bank with high reputation has higher level of customer loyalty.

The penalties from government inspectors is one important signal of reputation damage. According to the previous research, after the investigation of SEC, the market share of investment bank would decrease dramatically. This paper makes use of the sample of penalties of China Securities Regulatory Commission (CSRC) on investment banks and its sponsors between 2004-2015. This is aimed at investigating the issuers' reaction to these penalties and analyzing the impact of penalties on customer loyalty. The results show that after getting the penalties from government inspectors, the IPO customers of investment bank are more likely to change their underwriters. The impact is more significant for high-reputation investment banks.

The contributions of this paper include: firstly, this paper provide empirical evidence to prove that penalties do have effect on the reputation of investment bank. The penalties of government inspectors provide useful information to the public to assess the quality of underwriting services provided by different investment banks and therefore help the functioning of the investment bank's reputation mechanism. Secondly, the previous papers that show the relationship between reputation and customer loyalty of investment banks have the problem of endogenous choice between public companies and investment banks. Introducing penalties which are exogenous events could help solve this problem.

This paper is structured as follows: section two will introduce Chinese investment banks and the regulations of Chinese government; section three will critically review the previous literatures and section four will state the research hypothesis; the data, methodology and empirical results will be explained in section five. This paper will close with a small conclusion.

\section{Regulatory Background}

In the process of the development of Chinese Security market, the role played by investment bank has changed significantly. Before 1999, the issuing of securities must be approved by the government. With this rule, investment bank barely did their job. Local government played an important in the process of choosing the company that went public. Thus, the issuing price of securities was based on the profits or expected profits and fixed PE ratio. There was little the investment bank could do to choose the company or set the price. The major work done by the investment bank at that time was to help the company restructure and underwrote its securities. Between 1999-2003, investment bank recommended the company to go public and negotiate the issuing price with customers. Consequently, the issuing price must be approved by CSRC. Since 2004, the application of sponsor mechanism started. Both sponsor and 
investment bank are responsible for recommendation work. The job of investment bank include guidance of the work before going public, recommendation, underwriting, setting issuing prices, and providing continuous guidance after going public.

In order to increase the quality of underwriting services provided by investment bank, government inspectors have set a series of rules and guidance. According to the regulations, if investment bank provides false or mis-leading statement or missed any important message during underwriting, issuing and trading process, it will be warned or fined. The illegal gains would be confiscated and the security business license will be suspended or cancelled. In the "Securities Act" published in 1999, criminal liability and civil compensation were included in the penalties of investment banks. Since 2004 when sponsor system was introduced, the regulation and penalties of sponsor were clearly stated. There are empirical cases for the previous regulation and laws; however, how do these regulations impact the investment bank? Hence, there are limited researches that discuss this issue. This paper focuses on answering this question.

\section{Literature Review}

Beatty et al. (1998) used 29 investigation cases of SEC as a sample to discuss the effects of reputation damage on investment banks. The research shows that after being investigated by the government inspectors, the market share of IPO underwriter decreased significantly and the time duration from registration to successfully issuing shares increased significantly. The share price of similar-size competitors of investment banks dropped and the volatility of previous customers' share prices increases. Moreover, the IPO underpricing of customers on the first day was significantly higher. Once the investigation information was exposed, the share price of underwriters' IPO customers dropped. Song and Uzun (2004) investigate the effects of customers' financial fraud on the share price of IPO underwriters within five years. The findings show that the exposure of financial fraud of customers has a negative effect on the shared price of its underwriters. The higher the loss caused by the financial fraud, the longer the hidden period of financial fraud. On the other hand, the higher the proportion of financial fraud customer, the more heavily the fall of underwriter's share price. At the same time, the more the sue cases of customers, the more significant the negative effects on the underwriters. This research indicates that the financial frauds of customers have significant effects on the underwriters' reputation. Chunling Huang (2005) used the case of Macat to discuss the effect of false listing on the underwriters. She found that after the exposure of false listing, the market share of China Southern Securities fell significantly. Chen et al. (2011) investigated the effects on the underwriters if their customers were found to 
have financial frauds within three years after IPO. They found that if the customers were involved in financial frauds, the market share of their underwriters would decrease significantly and the approval time of their next customers IPO would increase.

The literatures show that if the previous customers are found to have financial frauds or the underwriters are investigated by government inspectors, the market shared and the market value of underwriters will decrease significantly. This paper will expand the research and discuss the effect of government inspectors' penalties on customer loyalty. Beatty's et al. (1998) research compared the change of different index before and after the investment banks was investigated by the government inspectors. However, they did not compare it with the control group which indicates that their results might be affected by the mixed events. Furthermore, we apply the differencein-difference model to investigate the effects of penalties on investment banks.

\section{Research Hypothesis}

Good reputation is the solid foundation for the development of any agency. The investors prefer an investment bank with high reputation to lower the risk of information asymmetry and thus, lower issuers' cost of capital. Good issuers are more likely to hire investment banks with high reputation to send positive signal to the market and lower the cost of financing. Therefore, customer loyalty of high-reputation investment banks is normally higher.

When the reputation is damaged, the market will punish the agencies. Beatty's et al. (1998) research shows that after SEC published its investigation results, the market share of the investment would decrease significantly. Both Chen et al. (2011) and Chunling Huang (2005) found that the accounting frauds of public companies will damage the investment banks that help them go public and reduce the investment bank's market share.

After IPO, the relationship-type capital was built between underwriters and issuers. Hence, this makes the issuers prefer the IPO underwrite to carry out SEO for them. In addition, this reflects the value of the relationship-type capital of underwriters. Krigman et al. (2001) found that the higher the reputation of IPO underwriters, the lower the possibility that IPO customer would switch the underwriters. Jianghui Liu (2010) found that Chinese Companies are more loyal to the underwriters that have high reputation.

Fernando's et al. (2005) research shows when the companies decide to do IPO or SEO. Therefore, the higher the variance between changes of ranking of issuers' financing scale and changes of the ranking of underwriter's reputation, the higher the possibility of changing underwriters. The reputation of investment bank would be damaged after being fined by the government inspectors. In order to ensure the SEO process, it is more likely for the 
customer to change the underwriters. Therefore, the research hypothesis is given below:

H1: The IPO customer is more likely to change the investment bank if the bank get the penalties from government inspectors. The possibility of changing the investment bank will be higher if the reputation of this bank is high.

\section{Data, Methodology and Empirical Results}

This paper collected CSRC's penalty events or cases of sponsors or investment banks from 2004 to 2015 . During this period, the total number of penalties is 54 and they cover 29 sponsor agencies or investment banks.

As shown in Table 1, panel A summarized all the penalty cases of the investment banks. In 28 cases, the penalty was warning letter or regulatory talks. Thus, this kind of penalty will not influence the investment banks' business. In 4 cases, CSRC paused the business of investment bank for three months. This kind of penalty will influence the public application of its customers and thus negatively affect investment banks' business. Panel B summarizes the penalties of sponsor that worked for investment banks. In total, 99 persons were punished. 51 of them had regulatory talks and the business of 29 persons were paused. 19 sponsors' licenses were cancelled and they were not allowed to enter into the security market any more.

Table 1 . The summary of CSRC's penalties between 2004-2015

\begin{tabular}{ll}
\hline PANEL A Penalties to investment banks & \\
\hline Warning letter or regulatory talks & 24 \\
\hline Pause business for 3 months & 4 \\
\hline Total & 28 \\
\hline PANEL B Penalties to individual sponsors & 51 \\
\hline Warning letters or regulatory talks & 29 \\
\hline Pause business for 3/6/9/12 months & 19 \\
\hline License cancelled and prohibit from entering the market & 99 \\
\hline Total
\end{tabular}

The samples used in this study were companies that did RS or SEO within 5 years after going public during 2004-2015. The initial number of the sample is 579. The companies that went public before 2004 or missed underwriter information were excluded. The feature data of IPO and SEO of 32 companies are missing, which is also excluded in this research. Only the first SEO after IPO are used, which exclude 104 companies which has twice or more SEOs. 26 IPO are excluded because they were not approved by CSRC. The final number of observation is 421 .

According to Bertrand and Mullainathan (2003) and Yang (2012), this paper built a difference-in-difference model: 


\section{CHANGE $\mathrm{i}, t=\mathrm{PUNISH}+\mathrm{POST}+\mathrm{PUNISH} P \mathrm{PER}+\mathrm{POST}$ PPER+CHGREPU +SAMEPROV+PERIOD+ROE_SEO+SIZE_SEO+PB_SEO+RETFD+SEO PROED+YEAR+UNDERWRITER}

Subsequently, the variables are described below:

CHANGE: If the company changes the underwriter when they do $\mathrm{SEO}$, the value is 1 , otherwise, the value is 0 .

PUNISH: If the investment bank got punished, the value is 1, otherwise the value is 0 . This variable is used to control the differences in change probability between the investment banks that got punished and those that were not punished. POST is the main test variable. For the year that the investment bank got punished and three years after, the value is 1, otherwise the value is 0 . This variable is used to test the effect of punishment events on customer loyalty of investment bank, compared to those investment banks that did not get punished at year $t$.

PUNISH_PER: If the sponsor of investment bank got punished by CSRC (exclude the situation when both investment bank and its sponsors got punished), the value is 1 , otherwise the value is 0 . POST-PER is the main test variable. For the year that the sponsor got punished and three years after, the value is 1 , otherwise the value is 0 . This variable is used to test the effect of punishment events on investment bank, compared to those investment banks whose sponsors were not punished. YEAR is a year dummy variable which is used to control the changing process of IPO underwriters' charging fee. UNDERWRITER is an investment bank dummy variable which is used to control the fixed effect of investment banks on its charging fee.

If the investment bank and its sponsors got punishment at different point in time, when the punishment event occurs, the punished investment bank is regarded as the treatment group. Other investment banks that were not punished at year $t$ is the control group. The parameters of variable POST and POST_PER measures the effect of punishment events on the investment banks that got punishment, compared to those that were not punished.

The controllable variables include: CHGREPU which is the changes of investment bank's ranking when they did IPO and SEO for the customer. The ranking of investment bank is dependent on the total revenue of underwriting (including IPO and SEO) for the previous three years. Femando et al. (2005) found that the higher the reputation of investment bank, the lower the possibility for the customer to change the underwriter when they carry out SEO. SAMERPROV is 1 if the registration place of investment bank is the same as the public company, otherwise it is 0 . This variable aims to control the geographic effects on customers' choice of underwriters.

The feature variable of issuers: RETFD refers to the decrease/increase of share price on the first day of IP. This variable is, however, used to control the effect of the performance of underwriters on customer choice. The longer 
the period which measures the duration of IPO (the public day) and SEO (declare day), the less important is the relationship-type capital between investment bank and public company. This means the possibility of customer to change the underwriter is higher (James, 1992); SEOPROED is the natural logarithm of financing scale of SEO. Therefore, the larger the scale, the higher the bargaining power of customer, and the more likely customers will change the underwrite (Krigman et al., 2001). The financial data of issuers include (based on previous year): Return on equity (ROE), natural logarithm of total assets (SIZE), and closing share price of previous year to the closing balance of net asset per share (PB). These variables are used to control the effect of the performance of customer companies based on its decision to change the underwriter (Fernando et al., 2005). Finally, this model control the years and investment banks as dummy variables.

Table 2 is the statistic description of CSRC's regulation and changes of underwriter when the companies do SEO. Among 421 sample, 249 companies (59\%, change group) changed their underwriters, while 172 companies (41\%, non-change group) did not change. Within change group, $53 \%$ of the underwrites had got the penalties during the period (2004-2015). In non-change group, $62 \%$ of the underwrites had got the penalties during the period (2004-2015). It shows that more underwriters among the non-change group had been punished. Among those 249 companies that had changed the underwriters when they perform SEO, 34\% of SEO were within three years after the underwriters were punished. In non-change group, this percentage is $28 \%$. More companies in change group had changed their SEO underwriter within three years. Nevertheless, the variance is not significant. The variance between the ranking of underwriter when the customer does IPO and SEO (CHGREPU) is significantly lower in the change group, compared to the nonchange group. That means the higher the reputation of underwriter, the less likely customers will change the underwriter when they perform SEO. In terms of the variable that measures whether the issuers and IPO underwriter are in the same place (SAMEPROV), non-change group is 22\%. Thus, this is higher than change group, but the variance is not significant. The duration of the time (LNPERD) of change group is significantly higher than non-change group. There is no significant difference between the change of share price on the first date (RETFD) of the change group and non-change group. It is the same for the financing scale and total asset scale. In terms of ROE, non-change group is significantly higher than change group. Change group has a higher $\mathrm{PB}$ value. 
Table 2. Statistic description of the variance between change group (249 companies) and non-change group (172 companies)

\begin{tabular}{|c|c|c|c|c|c|c|}
\hline & \multicolumn{2}{|c|}{ Change group (249) } & \multicolumn{4}{|c|}{ Non-change group（172） } \\
\hline Variable & mean & p50 & mean & $\mathrm{p} 50$ & $\mathrm{t}$ & $\mathrm{z}$ \\
\hline PUNISH & 0.53 & 1 & 0.62 & 1 & $1.87 *$ & $1.87 *$ \\
\hline POST & 0.34 & 0 & 0.28 & 0 & 1.22 & 1.22 \\
\hline PUNISH_PER & 0.55 & 1 & 0.60 & 1 & 0.91 & 0.91 \\
\hline POST_PER & 0.20 & 0 & 0.26 & 0 & 1.26 & 1.36 \\
\hline REPU & 0.45 & 0 & 0.51 & 1 & 1.05 & 1.05 \\
\hline CHGREPU & 0.03 & 0.02 & 0.05 & 0.03 & $2.03 * *$ & 1.69 \\
\hline SAMEPROV & 0.18 & 0 & 0.22 & 0 & 0.91 & 0.91 \\
\hline PERIOD & 7.37 & 7.38 & 7.08 & 7.13 & $6.56 * * *$ & $6.03 * * *$ \\
\hline RETFD & 88.96 & 62.19 & 85.13 & 51.98 & 0.42 & 0.8 \\
\hline SEOPROED & 20.15 & 20.09 & 20.13 & 20.08 & 0.28 & 0.22 \\
\hline ROE_SEO & 0.09 & 0.09 & 0.12 & 0.11 & $3.02 * * *$ & $2.95 * * *$ \\
\hline SIZE_SEO & 21.35 & 21.11 & 21.33 & 21.27 & 0.3 & 0.49 \\
\hline PB_SEO & 4.03 & 3.21 & 4.66 & 4.02 & $2.34 * *$ & $2.68 * * *$ \\
\hline
\end{tabular}

Table 3 shows the regression result. The parameters of POST shown in the first column are positive. This indicates that compared to other SEO which happens within three years since the underwriter got punished, the issuers would change the underwriters. This is consistent with the expectation. The parameters of POST_PER is not significant, which means the effects of the penalties of sponsors on the changes of SEO underwrites is limited. The parameters of REPU*POST have a positive significant value and the parameters of POST are no longer significant. Thus, this indicates that compared to the underwriters with low reputation, the IPO customers are more like to change the underwriters with high reputation after penalties. The impact of penalties on the investment bank that has high reputation is higher. The parameters of POST_PER in the second column have a negative significant value and the parameters of REPU*POST_PER have a positive significant value. This means that for the investment bank that has low reputation, the penalty would not negatively affect the sponsors and it would lower the possibility of changing the underwriter. However, the negative impact is higher to the investment bank with high reputation.

Among the controllable variables, the parameter of CHGREPU is negative, which means the more the underwriter increase its reputation, the less the customer would change the underwriter. This results indicate that the changes of underwriter's reputation is important to the customers' choice of SEO underwriters. The parameter of PERIOD is positive, which means the longer the duration between SEO and IPO, the easier the customer would change the underwriter. The parameter of ROE is positive, which means if the profitability of customer is higher, it is less likely for them to change the SEO underwriter. The parameter of RETFD is positive but not significant. 
Consequently, this is consistent with the results of previous literatures. There is not cause and effect relationship between IPO underpricing on the first day and the changes of SEO underwriter.

Table 3. Regression result

\begin{tabular}{|c|c|c|}
\hline & $\begin{array}{l}\text { (1) } \\
\text { CHANGE }\end{array}$ & $\begin{array}{l}(2) \\
\text { CHANGE }\end{array}$ \\
\hline PUNISH_INST & $\begin{array}{l}-0.595 \\
(-0.29)\end{array}$ & $\begin{array}{l}0.151 \\
(0.12)\end{array}$ \\
\hline POST & $\begin{array}{l}0.851^{* *} \\
(2.10)\end{array}$ & $\begin{array}{l}-0.747 \\
(-0.88)\end{array}$ \\
\hline PUNISH_PER & $\begin{array}{l}0.330 \\
(0.18)\end{array}$ & $\begin{array}{l}1.629 \\
(1.25)\end{array}$ \\
\hline POST_PER & $\begin{array}{l}-0.433 \\
(-1.04)\end{array}$ & $\begin{array}{l}-2.210^{* *} \\
(-2.00)\end{array}$ \\
\hline REPU & & $\begin{array}{l}-0.835 \\
(-0.65)\end{array}$ \\
\hline REPU*POST & & $\begin{array}{l}1.938^{* *} \\
(2.12)\end{array}$ \\
\hline REPU*POST_PER & & $\begin{array}{l}2.159^{*} \\
(1.81)\end{array}$ \\
\hline CHGREPU & $\begin{array}{l}-3.451^{* *} \\
(-2.25)\end{array}$ & $\begin{array}{l}-3.314^{* *} \\
(-2.09)\end{array}$ \\
\hline SAMEPROV & $\begin{array}{l}-0.044 \\
(-0.12)\end{array}$ & $\begin{array}{l}-0.097 \\
(-0.27)\end{array}$ \\
\hline PERIOD & $\begin{array}{l}2.119^{* * * *} \\
(5.52)\end{array}$ & $\begin{array}{l}2.144^{* * * *} \\
(5.50)\end{array}$ \\
\hline ROE_SEO & $\begin{array}{l}-5.533^{* *} \\
(-2.31)\end{array}$ & $\begin{array}{l}-5.685^{* *} \\
(-2.32)\end{array}$ \\
\hline SIZE_SEO & $\begin{array}{l}-0.238 \\
(-0.96)\end{array}$ & $\begin{array}{l}-0.237 \\
(-0.93)\end{array}$ \\
\hline PB_SEO & $\begin{array}{l}0.027 \\
(0.36)\end{array}$ & $\begin{array}{l}0.034 \\
(0.44)\end{array}$ \\
\hline RETFD & $\begin{array}{l}0.002 \\
(1.40)\end{array}$ & $\begin{array}{l}0.002 \\
(1.33)\end{array}$ \\
\hline SEOPROED & $\begin{array}{l}0.395 \\
(1.63)\end{array}$ & $\begin{array}{l}0.402 \\
(1.63)\end{array}$ \\
\hline $\begin{array}{l}\text { YEAR } \\
\text { UNDERWRITER } \\
\text { _cons }\end{array}$ & $\begin{array}{l}\text { control } \\
\text { control } \\
-16.934^{* * * *} \\
(-3.18)\end{array}$ & $\begin{array}{l}\text { control } \\
\text { control } \\
-17.054^{* * * *} \\
(-3.16)\end{array}$ \\
\hline $\begin{array}{l}N \\
\text { pseudo } R^{2}\end{array}$ & $\begin{array}{l}356 \\
0.240\end{array}$ & $\begin{array}{l}356 \\
0.256\end{array}$ \\
\hline
\end{tabular}

\section{Conclusion}

This research used the penalty cases of CSRC between 2004 and 2015 to investigate the effects of penalties on customer loyalty of investment banks. We found that customers are more likely to change SEO underwriter if the IPO underwrite got punished. Hence, this confirms the research hypothesis of this paper. Moreover, for the investment banks with high reputation, this negative impact on customer loyalty is more significant. 


\section{References:}

1. Beatty, R.P., Bunsis, H., \& Hand, J. (1998). The indirect economic penalties in SEC investigations of underwriters, Journal of Financial Economics, 50,151-186.

2. Bertrand, M. \& Mullainathan, S. (2003). Enjoying the quiet life? Corporate governance and managerial preferences, Journal of Political Economy 111, 1043-1075.

3. Carter, R. \& Manaster, S. (1990). Initial Public Offering and Underwriter Reputation, Journal of Finance 45, 1045-1068.

4. Carter, R., Dark, F.H., \& Singh, J.K. (1998). Underwriter Reputation, Initial Returns, and the Long-Run Performance of IPO Stocks, Journal of Finance 53, 285-311.

5. Chang, S., Chung, T., \& Lin, W. (2010). Underwriter reputation, earnings management and the long-run performance of initial public offerings, Accounting and Finance 50 (2010) 53-78.

6. Chen, D., Guan, Y., Zhao, G., \& Wu, F. (2011). Securities regulation and implicit penalties, China Journal of Accounting Research, 4, 4762.

7. Chen, C., Shi, H., \& Xu, H. (2014). The IPO underwriting market share in China: Do ownership and quality matter? Journal of Banking \&Finance, 46:177-189.

8. Chen, C., Shi, H., \& Xu, H. (2013). Underwriter reputation, Issuer ownership, and Pre-IPO earnings management: evidence form China, Financial Management, Fall, 647-677.

9. Chunling Huang (2005). The efficiency of regulation in securities market and reputation of underwriter----case study of "McEntee Event" of China Southern Securities, Management World, Volume 7, 129-138.

10. Dunbar, CG. (2000). "Factors Affecting Investment Bank Initial Public Offering Market Share," Journal of Financial Economics 55, 3-41.

11. Espenlaub, S., Khurshed, A., \& Mohamed, A. (2012). IPO survival in a reputational market, Journal of Business Finance \& Accounting, $39(3) \&(4), 427-463$.

12. Fang, L.H. (2005). "Investment Bank Reputation and the Price and Quality of Underwriting Services," Journal ofFinance 60, 2729-2761.

13. Fernando, C.S., Gatchev, V., \& Spindt, P. (2005). Wanna dance? How firms and underwriters choose each other, Journal of Finance, 60, 243 7-2469.

14. Firth, M. (1990). Auditor reputation: the impact of critical reports issued by government inspectors, RAND Journal of Economics, 21, 374-378. 
15. Huyghebaert, N. \& Xu, W. (2015). What determines the market share of investment banks in Chinese domestic IPOs? China Economic Review, 34, 150-168.

16. James, C. (1992). Relationship-specific, assets and the pricing of underwriter services, The Journal of Finance, 5, 1865-1885.

17. Jianghui Liu (2004). Research of the relationship between Chinese underwriter's reputation and underwriter fee, Journal of Finance and Economics, Volume 4, 108-118

18. Jianghui Liu (2010). Why Chinese public companies change their SEO underwriters - customer loyalty perspective, China Finance Review, Proceedings of International Conference Paper, 34-53

19. Jo, H., Kim, Y., \& Park, M.S. (2007). Underwriter Choice and Earnings Management: Evidence from Seasoned Equity Offerings, Review of Accounting Studies 12, 23-59.

20. Krigman, L., Shaw, W.H., \& Womack, K. (2001). Why do firms switch underwriters? Journal of Financial Economics, 60, 245-284.

21. Lee, G. \& Masulis, R.W. (2011). Do more reputable financial institutions reduce earnings management by IPO issuers? Journal of Corporate Finance, 17, 982-1000.

22. Lennox, C. \& Li, B. (2014). Accounting misstatements following lawsuits against auditors, Journal of Accounting and Economics, 57, 58-75.

23. Nanda, V. \& Yun, Y. (1997). Reputation and Financial Intermediation: An Empirical Investigation of the Impact of IPO Mispricing on Underwriter Market Value, Journal of Financial Intermediation, 6, 3963.

24. Piotroski, J., Wong, T.J., \& Wu, D. (2012). Government Intervention and the Development of China's Financial Intermediaries: Efficiency or Political Opportunism? Working paper.

25. Song, W.L. \& Uzun, H. (----). The Impact of Clients' Alleged Financial Reporting Fraud on Underwriter Reputation, Working paper.

26. Su, C. \& Bangassa, K. (2011). The impact of underwriter reputation on initial returns and long-run performance of Chinese IPOs, Journal of international Financial Markets, Institutions \& Money, 21:760-791.

27. Swanquist, Q. \& Whited, R. (2015). Do Clients Avoid 'Contaminated' Offices? The Economic Consequences of Low Quality Audits, Accounting Review, 90, 2537-2570.

28. Yang, Z. (2012). Do political connections add value to audit firms? Evidence from IPO audits in China. Contemporary Accounting Research 30 (3): 891-921. 